\title{
PIONEER
}

VOLUME 12, Issue 1, June 2020: 27 - 42

\section{A COMPARATIVE STUDY ON ENGLISH AND FRENCH SIMPLE PERSONAL PRONOUNS}

\author{
Beny Hamdani \\ Islamic University of Zainul Hasan Genggong Probolinggo \\ benyhamdani.ielts9.consultation@gmail.com
}

\begin{abstract}
This paper critically aims to explain and describe the comparison between English and French simple personal pronouns. The comparison will be based on the form of simple personal pronoun related to the gender and show the similarities and dissimilarities between English and French simple personal pronouns. The method that is used in this study is descriptive method which covers descriptive and comparative techniques. In collecting the data, a number of books which are related to this research have been analyzed. This study reveals some results: (1) The inflection of French personal pronoun changes fully, (2) The declension of personal pronoun is complex according to gender beginning with the first person, second person and third person. Each declension of French has a specific form depending on gender. The form of predicate is wide according to the gender, (3) The inflection of English personal pronoun is simpler than French because some terms of its declension have the same form (e.g. I, We, You, They), and (4) The declension of French personal pronoun is complex and has a close relation with the predicate, because French verbs have three kinds of conjugation and its personal pronoun has its personal endings for the each term.
\end{abstract}

Keywords: comparative study, pronoun, English, French

\section{INTRODUCTION}

Language is a system for the communication of meaning and every language meets the communicative needs of its users (Julia, 1978:7). In other words, language is a means of communication among people. It is a kind of idea or concept used by people transferring and sharing information, feelings, experiences, knowledge, and as well to understand, persuade, and convert the others. By using language, we want to achieve a certain effect and also consider that our communication will be successful to attain our purpose. Hornby (1987:473) states that "Language is human and non-instinctive method of communicating ideas, feeling and desires by meaning of a system of sounds and sounds symbols".

Furthermore, language is not only seen by the object to be explored but also takes a vital function in many different aspects of the life such as social, military, economics or even politics. English that comes from Indo-European language is 
acknowledged to be an international language which its use is wide. It is not only the language of England but of the extensive domination of colonies associated in the British Empire, it is also the language of the United States and Australia (Baugh, 1957:4) spoken by over 260 million people. Thus at the present time, English has the advantages in number over all other western languages. English however, is not the largest language in the world. There are still many languages spoken by million people such as Chinese, Spanish, Arabic, French, Italian and also Russian.

The importance of language is not a matter of number or territory. It depends also on the importance of the people who speak with it. The importance of the language is inevitable associated in the mind of world with the political role played by the nations using it and their influence in international affairs. Because of that, the great of English is influenced by the extensive dominions and colonies, political influence, economy soundness, commercial activity, science and also religion.

Comparative study in Linguistics is an effort to show the dissimilarities between two languages. Antilla (1972:316) states that a practical aspect of typology is comparative study where by two languages are contrasted by dismembering them into their components and matching the components as possible in the framework of semantic equivalents. Next, Langacker (1973:6-9) states that comparative study is very important, especially in teaching, because it can be used as the basis of material selection. In other words, Lado (1974:1-9) states that comparative study need to consider not only linguistic contrast but also pragmatic contrast, like the similarities and differences in the stylistic use of items in the first and the second languages and in form function relationship.

The development of modern English is inevitably influenced by Latin language to old English. The greatest influence of Latin upon old English was occasioned by the introduction of Christianity into Britain in 597. The new faith was far from new in island, but this date marks the beginning of systematic attempt on the part of Rome to convert the inhabitants and make England a Christian country. The same goes for French. This language is also the language of written communication and of the most oral communication for the speakers of French. French also comes from Indo-European Family languages especially from Western Indo-European Family languages. We find Italics as a branch of Indo-European Italy, and the most people of Italy in ancient times 
suggest Rome and the languages of Rome and Latin. Latin was spread into all the Roman Empires. The various language of which represents the survival of Latin in the different parts of the Roman Empires are known as the Romance or Romanic Language. Some of them have since spread into other territory, particularly in the new world. The most extensive of the Romance languages are French, Spanish, and Italian. French is primarily the language of Northern France although it is the languages of literature and education throughout the country. The history of French was begun when the Roman came to Gaul, the ancient of France, six years before the birth of Christ. It is one of the most important of the Roman languages, those languages that grew out of the tongue of the ancient Roman (Didiler, 1975:14).

There are hundreds of French words used in English as we already know. In some countries where a number of people from different lands live and work, French is a second language for social usage, while English is generally used as a second language for business purposes (Lindquist, 1962:98). By understanding the background of the two languages above, it is important to master them well although they come from different branches of Indo-European languages. However, they still have the same role of language such as parts of speech, phoneme, morpheme etc.

More than half of English vocabularies are used in the same from in French, however we cannot generalize that all the English form have the similar form in French, because it will be different especially if we use the form of English that came from Anglo-Saxon. Finally, there is still global contact to enrich English vocabularies by borrowing some words from other countries e.g. Italy, Spanish, Portuguese, Arabic, Turkey, Dutch, and China.

As described previously, the problem to discuss is that to know the comparison between English and French simple personal pronouns. The significances of the study are that this research can contribute a better understanding of the use of English and French simple personal pronoun and it will be an important reference to the further discussion on the same case study or to give the reader clearer understanding to study both English and French. Furthermore, it is also intended for readers who are interested in the comparative analysis of English and French. 


\section{REVIEW OF LITERATURE}

Both English and French belong to Indo-European family, but English is one of Germanic groups and French Romance. Despite the fact that the history of Normandy Conquest is more than nine centuries long, the effect of French on English is beyond measure. After Normandy Conquest, abundant French words were flooded into English, exerting a great influence on the development of English. Since the two languages are similar in such aspects as pronunciation, lexicology and grammar, the study of the relationship between them has always been a hot spot to discuss in the study of foreign languages.

English is a descendent of Indo-European family of languages. It was the branch of Germanic. The reason is that the most English words that are spoken now are Germanic Origin. The history of English language in England begins with settlement of the three Germanic tribes. There are angles, Saxon and Jutes, in the middle of the fifth century. The grouping of tribes was not very permanent, since a vigorous ruler sometimes succeeded for a short time in uniting two or more kingdoms, but seven kingdoms can be distinguished as having a fairly stable existence, and three are described as the Anglo-Saxon Heptarchy (Brook, 1958:40).

Since language is constantly changing it is possible to divide the history of the English language as spoken in England into three periods, known respectively as Old English, Middle English and Modern English. The old English period extends from the time of the earliest surviving written documents in the eight century until the end of the eleventh century; the Middle English period extends from the end of the fiftieth century until the present day.

In other words, French was from the Indo-European family languages and it was one of the branches of Italic or Latin. It is spoken by some 75 million people of the world (Lindquist, 1962:205). This language is one of the important languages of international diplomacy that is used in some conferences. French is one of the most important of the Roman Languages, those languages that grew out of the tongue of the ancient Roman. The Roman came to Gaul, the ancient name of France, about six years before the birth of Christ.

The various languages that represent the survival of Latin in the different part of the Roman Empire are known as the Romance or Romanic Languages. Some of them 
have since spread into other territory, particularly in the new world. The most extensive of the romance languages are French, Spanish, Portuguese, and Italian. French is primary the language of Northern France although it is the language of literature and education throughout the country. There were a number of dialects in the Middle Ages; some of them are Norman, Picard, burgundies and that of the Ile-de-rance. But with the establishment of the Capetiants is as kings of France and the rise of Paris as the national capital city. The dialect of Paris or ile-de-France gradually won recognition as the official and literacy language. Since the thirteenth century the Paris dialect has been standard French (Baugh, 1985:26).

\section{METHOD}

This study uses descriptive method which covers descriptive and comparative techniques. The descriptive research is aimed to solve the problems in recent time (Surachmad, 1990:139). The data of this study are collected by doing library research. For this study, the writer has read a great deal of Linguistics books. The data are collected from the explanation of English and French personal pronouns and the inflection of the two languages. The type of the data is qualitative data with descriptive analysis.

\section{FINDINGS AND DISCUSSION}

\section{Findings}

English and French come from Indo-European family of languages; English was descendent of Indo-Germanic, the language spoken by the Germanic invaders of England in 1449. It had many inflections. Inflections are changes in the forms of words to express changes of meaning, especially grammatical meaning. Early English used many more of these inflections than we do today. But even in Old English some inflections were passing out of use, During the long period when French was the official language of England many more inflections were lost, especially in the middle English period, English changes greatly. It was simplified in grammar by the loss of ending or words and it absorbed many words from French.

French came from the Indo-European family languages and it was one of the branch of Italic or Latin. It is spoken by some 75 million people of the world. This language is one of the important languages of international diplomacy that is used in 
some conferences. French is one of the most important of the roman languages, those languages that grew out of the tongue of the ancient Roman. The Roman came to Gaul, the ancient name of France about six years before the birth of Christ.

Rome's world power converted Latin into an international language spoken in the entire western part of the Roman Empire and in some parts of the Balkan Peninsula. It became the parent language of a group of widely spread language now living, and it can be traced by loan words all the way to Armenia and Arabia. As a learned language it dominated Western Europe throughout the middle Ages and well into modern times. The Romance languages which are descended from Latin, and whose independent existence can be reckoned as beginning with the eighty century after Christ are as follows.

1. Portuguese.

2. Spanish (Castilian).

3. Catalan (in eastern Spain)

4. Provencal (in the southern third of France).

5. French.

6. Rhaetoromanic (in the Grisons, tyrol and Friuli).

7. Italian.

8. Dalmation (Extint, crowded out by Italian).

9. Rumanian.

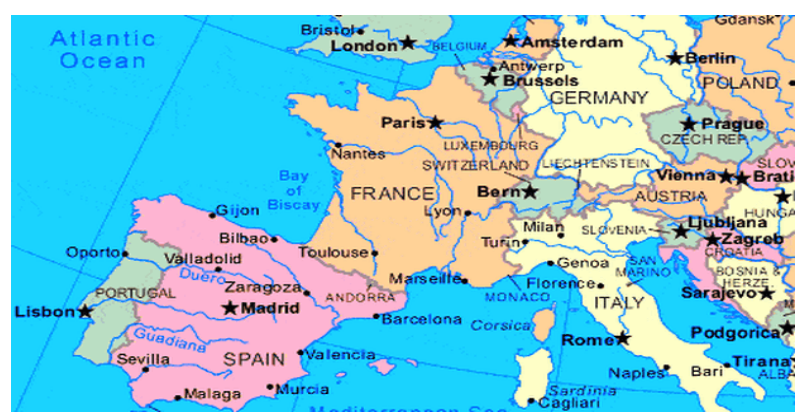

Figure 1. Map of France

English is a descendent of Indo-European family of languages. It was the branch of Germanic; the reason is that the most English words that are spoken now are Germanic Origin. The history of English language in England begins with the 
settlement of the three Germanic tribes, they are Angles, Saxon and Jutes, in the middle of the fifth century. The grouping of tribes was not very permanent since a vigorous ruler sometimes succeeded for a short time in uniting two or more kingdoms, but seven kingdoms can be distinguished as having a fairly stable existence, and there are described as the Anglo-Saxon Heptarchy (Brook, 1958:40)

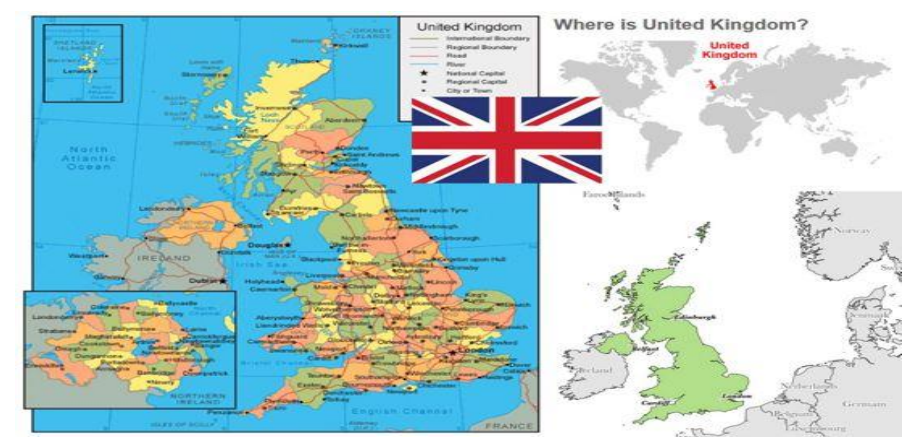

Figure 2. Map of England

Modern English is a language with only a few surviving inflections, and some of these like the special forms for the subjunctive are adding out, The change from Latin into Old French was completed about 1100. Its growth from Latin and popular Latin saw many changes. The forms of the personal pronouns are different, because they come from different branches of family tree. However they still have the same function in the sentence structure i.e. nominative or subjective, objective and possessive.

The personal pronoun is inflected by number, gender and case. According to the number English personal Pronoun may stand either in the singular or in the plural.

1. Singular : Consists of one person or thing (I, you, he, she, it)

2. Plural : Consists of more than one person (We, You, they)

The first, the second and the third person do not denote gender, their gender being determined by their noun antecedent, and the third person singular forms indicate gender. Unlike nouns, most of the personal pronoun have different forms for the objective and nominative vases: I-me, We-us, he-him, she-her, they-them. The inflection of pronouns is called declension and the changing of the forms to show changes in Gender, case, or number is called declining.

The forms given in the following declension of the personal pronoun show all of the inflection changes of the simple personal pronoun. 
Table 1. Inflection changes of the simple personal pronoun.

\begin{tabular}{ccc}
\hline First Person & Singular & Plural \\
\hline nominative & I & we \\
\hline posessive & my, mine & our, ours \\
\hline objective & me & Plural \\
\hline Second Person & Singular & you \\
\hline nominative & you & your, yours \\
\hline posessive & your, yours & you \\
\hline objective & you & Plural \\
\hline Third Person & Singular & masc, fem, neut \\
\hline nominative & masc, fem, neut & it, they \\
\hline posessive & he, she & its, their, theirs \\
\hline objective & his, her, hers & it, them
\end{tabular}

The clearer description will be discussed in the following assertion.

\section{First Person}

\section{First Person Singular}

The first person singular (I, me, my, mine) is used by one person, masculine and feminine, so the speaker is a person either masculine or feminine.

\subsection{Nominative or Subjective case}

Example ; I buy some flowers. I'achete des fleurs.

I have some soup. I'ai de la soup.

\subsection{Objective case}

There are four kinds of objects in the objective case.

a. Direct Object e.g. He loves me. Il m'aime

b. Indirect object e.g. The teacher gives me a book. Le professeur me donne le livre.

c. Object of preposition e.. They will go with me. Iis iront avec moi.

d. Subject of an infitive e.g. Mother asked me to buy a bottle of milk. Ma meme me demande acheter une beuteille du lait.

\subsection{Possessive case}

There are two types of English possessive i.e: 
a. Possessive adjective : my book is new. Mon livre est neuf.

b. Possessive Pronoun: Whose book is this? Mine a qui est cet livre? Le mien.

Possessive pronoun are used to replace possessive adjective and plus noun.

2. First Person Plural

The first person plural (we, us, our, ours) refers to plural number, means two people or more. It is used when one speaking for a group of person including himself.

\subsection{Nominative Case}

In nominative case the subject "we" requires the plural form of the verb.

E.g. we invite our friends. Nous invitons nos amies.

We arrive on time. Nous arrivons a l'heure.

\subsection{Objective case}

a. Direct Object: She punishes us. Elle nous punit.

b. Indirect Object: My father gives us some books. Mon pere nous donne des livres.

c. Object of preposition: They are speaking to us. II nous parlent.

d. Subject of infinitive: She tells us to come on time. Elle nous dit arriver a l'heure.

2.3. Possessive Case

a. Possessive adjective: Our car is new. Notire voiture est neuve.

b. Possessive Pronoun: Is he speaking about hers? Parle-t-il du sien?

\section{Second Person}

The second person "you" has fewer inflectional forms than other personal pronouns. The same form "you" is used for nominative and objective singular or plural, masculine or feminine. The pronoun "you" requires the plural form of the verb either the meaning is singular or plural.

1. Nominative case. E.g. you are my best friend! Tu est mon mieux ami.

2. Objective case

a. Direct Object: He loves you. Ii t'aime.

b. Indirect Object: Peter gives you a present. Pierre lui donne un cadeau.

3. Possesive case

a. Possessive Adjective: Raise your hand! Le've la main.

b. Possesive Pronoun: You are using mine, where is yours? 
It is sometimes difficult to determine "you" whether it is a singular or plural meaning. The adjective "all" is often added to indicate the plural meaning,"all" must never use with "you" when the meaning is singular, e.g. You all must leave this class at 12.00 (plural)- Vous devez laisser la classe, quand i lest midi.

\section{Third Person}

The third person forms of the personal pronouns are more numerous than the first and the second person. The speaker or writer must keep in mind about the gender and third person can be divided into two groups, there are the third person singular and the third person plural.

1. The third person singular

1.1. The third person singular masculine

The third person singular masculine gender (he, him, and his) refers to masculine antecedents or to nouns that have unclear gender, In nominative it takes the singular of the verb.

a. $\quad$ Nominative Case: He works in the office. II Travaille au bureau.

b. Objective case

1. Direct Object: I see him. Je le vois.

2. Indirect Object: My father buys him a new shirt. Mon pere l'achete une chemise.

3. Object of prepositions: My sister writes a letter to him. Ma soeur ecrire pour lui.

4. Subject of an infinitive: The teacher asked him to finish the text. Le professeur lui demande finir le texte.

c. Possessive case

1. Possesive adective : He lowered his head. Il a baisse la tete.

2. Possessive pronoun: Those are mine where are his. Ce sont less miens, du sont les tiens?

1.2. The third person singular feminine

The third person singular feminine gender (She, her, and hers) refers to feminine nouns or the personified names of the objects that are assumed having feminine characters.

1. Nominative case : She answers the exercise. Elle reponde l'exercise.

2. Objective case

a. Direct Object. He loves her. II l'aime. 
b. Indirect Object: He gives her some flowers. iI la donne des fleurs.

c. Object of prepositions: The students talk with her. Les etudiants parlent avec elle.

d. Subject of an infinitive: Help her to carry the bag! Aidez-la! Emporter la sac.

3. Possessive case

a. Possessive Adjective: She raises her hand. Elle a leve la main.

b. Possessive Pronoun: It is not ours, it's hers. Ce n'est pas le notre. C'est le sien.

1.3. Third person singular neuter

The third person singular neuter gender (it, its) is normally used of a thing or an animal that its sex is known, the expression of time, distance, weather, temperature, tide and also can be used of people especially in conversation.

Examples :

- Where is her tie? Du est son cravat?

- $\quad$ It is on the table. Elle est sur la table.

- $\quad$ It is six. IL est six heures.

1.4 The third person plural

The third person plural (they, them, their, theirs) has the same forms for masculine, feminine and neuter, so the third plural forms do not denote gender, but they always denote plural number, and their antecedent must always be plural .

1. Nominative case: The boys were invited, but they did not come. Les garcons sont invite, mais ils n'arrivent pas.

2. Objective case

a. Direct Object: He invites me. iL les invite.

b. Indirect Object: She gives them some books. Elle leur done des livres.

c. Object of preprosition : She will go with them. Ele ira avec ells.

d. Subject of an invinitive : The teacher asked them to finish their homeworks. Les professeur ells finir leur exercises.

In French as in English, pronouns have different forms according to their use or position in a sentence. Like English, French personal pronouns are also inflected by number, gender and case. According to their number, French personal pronouns are divided into two forms that is singular and plural, there is a difference between French and English personal pronoun especially for the third person plural, in English we use "they" for the 
third person plural, but in French we distinguish the third person plural, but $\mathrm{n}$ French we distinguished the third person feminine plural (ells) and the third person masculine plural (ils).

Here is the detailed description about them:

1. A. First Person Singular : "Je" (I)

It is used by one person, masculine, and feminine (the speaker)

B. First person Plural: "Nous" (We).

It is used by more than one person masculine, feminine or masculine and feminine.

2. A. Second Person Singular: "Tu" (You)

It consists of one person feminine or masculine. 'Tu" is also use to address a friend, relative, or close associate, it is called the familiar singular form. To address someone that we do not know well or someone older than us, the pronoun "Vous" is used. It is called the formal singular form.

B. Second Person Plural: "Vous" (You)

It is used to address more than one person. Vous is the plural form for "tu" and vous singular form.

3. A. Third Person Singular : "IL" (He), "Elle" (She)

"Il is used to address a person masculine and "Ele" is used to address a person feminine.

B. Third Person Plural: "ILs (They), "Elles" (They).

"Il "is used when third person is more than one person and the gender is masculine and "Elles" is used when the person is more than one person and the gender is feminine.

Personal Pronouns also influence verbs and adjectives. French verbs are more complex, they require more endings, which varied according to the person and number of the subject. There are two kinds of French personal pronoun i.e: conjunctive and Disjunctive pronouns. Conjunctive pronouns mean pronouns that have direct relation with the verbs. The function could be a direct or indirect object.

After analyzing of inflection of personal pronoun it is found some similarities between English and French. Historically they come from the same family of language. English and French personal pronouns are inflected by gender. Thus each terms of personal pronoun change according to their gender. Besides, the inflection of gender of the third person is the same means that the first person singular is used by the speaker 
masculine or feminine, also the first person plural is used to refer plural number means two persons or more, masculine or feminine. This first person plural is used when one is speaking for a group of persons including himself.

English and French come from the same family of language but they still have some differences in some cases. By analyzing of inflection of personal pronoun it is found some dissimilarities between English and French. The inflection of French personal pronoun are more complex than English because there are some agreement between personal pronoun and adjective, personal pronoun and verb. French verbs are more complex, French verbs require more endings, which varied according to the person and number of subject, the inflections of verb Is called personal endings.

Each form of French personal pronoun has each term for second person and third person. Second person in French is distinguished between familiar singular (tu) and formal singular (vous). It does not happen in English, because the form "you". It does not happen in English, because the form "you" as the second person is used for nominative and objective singular masculine or feminine and also for nominative and objective plural. In addition, the third person singular of English has different form for neuter, French third person oes not have neuter form, there are only feminine and masculine. The third person plural in English there is only one form (they) but in French it is distinguished between feminine and masculine. So, the English third plural forms do not denote gender but they always denote plural number.

\section{Discussion}

After analyzing of inflection of personal pronoun it is found some similarities between English and French. Historically they come from the same family of language. English and French personal pronouns are inflected by gender. Thus each terms of personal pronoun change according to their gender. Besides, the inflection of gender of the third person is the same means that the first person singular is used by the speaker masculine or feminine, also the first person plural is used to refer plural number means two persons or more, masculine or feminine. This first person plural is used when one is speaking for a group of persons including himself.

English and French come from the same family of language but they still have some differences in some cases. By analyzing of inflection of personal pronoun it is 
found some dissimilarities between English and French. The inflection of French personal pronoun are more complex than English because there are some agreement between personal pronoun and adjective, personal pronoun and verb. French verbs are more complex, French verbs require more endings, which varied according to the person and number of subject, the inflections of verb Is called personal endings.

Each form of French personal pronoun has each term for second person and third person. Second person in French is distinguished between familiar singular (tu) and formal singular (vous). It does not happen in English, because the form "you". It does not happen in English, because the form "you" as the second person is used for nominative and objective singular masculine or feminine and also for nominative and objective plural. In addition, the third person singular of English has different form for neuter, French third person oes not have neuter form, there are only feminine and masculine. The third person plural in English there is only one form (they) but in French it is distinguished between feminine and masculine. So, the English third plural forms do not denote gender but they always denote plural number.

\section{CONCLUSION AND SUGGESTIONS}

\section{Conclusion}

This study reveals some conclusion. The inflection of French personal pronoun changes fully. The declension of personal pronoun is complex according to gender beginning with the first person, second person and third person. According to the structure, there must be a good relation between subject and predicate to make a god sentences. Each declension of French have a specific form, depends on gender. The form of predicate is wide according to the gender.

The inflection of English personal pronoun is simpler than French because some terms of its declension have the same form (e.g. I, We, You, They). So the speaker must not give a hard attention to say "I am a student" or "you go to campus" because I, We, You, They do not differ gender, they also do not change the form of verb, and the form of "you" does not differ in gender so the form of verb has a little changing, in simple present tense only adding "s or es" to verb according to the number of subject. The declension of French personal pronoun is complex and has a close relation with the 
predicate, because French verbs have three kinds of conjugation and its personal pronoun has its personal endings for the each term.

Moreover, in simple past tense, it is simpler than present tense because the form of verb does not change according to gender but all have the same form. Thus the speaker only gives attention to the form of verb whether it is regular or irregular. Based on the historical background, French is very familiar for English; French words came into England at different times and for different reasons. The first group of words came with the Normans. The second group came from the Parision French during the Middle English Period. The rest have come from Modern French, and more have continued to come, even down the present time, some of the early borrowing, have become so well absorbed into the English language that it is difficult for us to think of them as ever having been foreign.

\section{Suggestion}

For further study, the researcher suggests the same method be used in analyzing other types of grammar, namely tenses, noun clause and adverbial clauses. The researcher also suggests that this study be used as an aid to understand simple personal pronoun by those who are studying English and French.

\section{REFERENCES}

Antillo, R. (1972). An introduction to Historical and comparative Linguistics. New York: The Michillan Company.

Baugh, A.C. (1957). A history of the English Language. London: Routledges and Kegan Paul Ltd.

Brook, G.L. (1958). A history of the English Language. London: Andre Deutsh.

Didiler. (1975). Notre languge Francaise Grammaire. Bruxelle. Montreal. Paris

Djajasudarma, F. (1993). Metode Linguistik : Ancangan Metode Penelitian dan Kajian. Bandung: PT. Eresco.

Falk, J.S. (1978). Linguistics and Language. New York: John Wiley and Sons, Inc.

Hornby, A.S. (1987). Oxford Advanced Learner: A Dictionary of Current English. Oxford: Oxford University Press.

Lado, R. (1974). Linguistics Across Cultures. Ann Abror: The University of Michigan Press. 
Langacker, R.W. (1973). Language and Its structure. New York: Oxford University Press.

Lindquist, L. (1962). General Language: English and Its Foreign Relations. New York: Holt Rinehart and Winston, Inc.

Surachmad, W. (1990). Pengantar Penelitian Ilmiah Dasar Metode dan Teknik. Bandung: Tarsito. 